\title{
Impact of social capital and business operation mode on intellectual capital and knowledge management
}

\author{
Wann-Yih Wu* \\ Department of Business Administration \\ National Cheng Kung University \\ No. 1 University Road, Tainan 70101, Taiwan \\ Fax: 001-886-6-2752455 Email: wanyi@mail.ncku.edu.tw \\ *Corresponding author

\section{Hsin-Ju Tsai} \\ Manchester School of Management \\ University of Manchester Institute of Science and Technology \\ Manchester, UK
}

\begin{abstract}
Chief executives have recently identified knowledge management $(\mathrm{KM})$ as a 'must do' item for their firms. These executives have also contended that social capital is a catalyst in effectively implementing knowledge management. However, the mechanism through which social capital influences knowledge management requires further study. This study examines the influence of social capital and business operation mode on knowledge creating activities, intellectual capital (IC) and knowledge management effectiveness.

After a series of interviews with experts and a questionnaire survey, this study reached the following findings:

- firms implementing higher levels of authority delegation and social capital tend to engage in more knowledge-creating activities and have more intellectual capital

- levels of intellectual capital tend to significantly influence KM effectiveness

- social capital and delegation of authority are significant moderators of the relationships between knowledge-creating activities and intellectual capital.
\end{abstract}

Keywords: social capital; intellectual capital; knowledge-creating activities; knowledge management; knowledge management effectiveness.

Reference to this paper should be made as follows: Wu, W-Y. and Tsai, H-J. (2005) 'Impact of social capital and business operation mode on intellectual capital and knowledge management', Int. J. Technology Management, Vol. 30, Nos. 1/2, pp.147-171.

Biographical notes: Wann-Yih $\mathrm{Wu}$ is a Professor and Dean of College of Management, National Cheng Kung University, Taiwan. He received his doctorate in marketing from Oklahoma State University. His current research interests include marketing strategy, strategic alliance and quality management. He has published in Total Quality Management, Industrial Management and Data System, Journal of Advertising Research, and others.

Hsin-Ju Tsai is a PhD student in the Manchester School of Management at the University of Manchester Institute of Science and Technology, UK. Her current research focuses on marketing strategy and international management. 


\section{Introduction}

\subsection{Research motivation}

In a 1989 survey, most Fortune 50 CEOs agreed that knowledge is a fundamental determinant of general enterprise activity, and particularly enterprise success. These CEOs indicated that enterprise viability depends directly on competitive quality and successful exploitation of enterprise knowledge assets [1]. About ten years later, another study conducted in 1999 also demonstrated that 'knowledge management (KM)' ranked second only to 'globalisation' as a priority for Fortune 50 CEOs [2]. Thus, knowledge generation and knowledge management recently have been widely recognised as two keys to successful business operation.

According to Shariq [3], as we enter a new era, the future will be determined by our ability to exploit knowledge. To achieve success, firms must develop a comprehensive understanding of the creation, transfer and deployment of knowledge management [3]. The process of generating and managing knowledge is critical in creating competitive advantage [4]. Wiig [1] identified three distinct approaches to knowledge management. The first approach stresses managing explicit knowledge using technical methods, including computer knowledge bases, knowledge-based systems, and so on. The second approach focuses on managing organisational intellectual capital (IC), which comprises human capital, customer capital, and structural capital. Finally, the third approach includes all relevant knowledge-related aspects that may influence organisational performance and success [1]. Little effort has been made to integrate these three approaches into a single comprehensive research framework and conduct further empirical validation of relevant research constructs.

Additionally, Sullivan [5] stated that firm intellectual capital includes human capital, customer capital and structural capital. The interrelationships between human capital, customer capital, and structural capital have been the subject of major concern among scholars and practitioners in recent years. Some argued that in a real business operation system, human, structural, and customer capital should work together and support or detract from one another [6].

Furthermore, the contingency perspective of knowledge management has attracted considerable attention. The comment has been made that to improve knowledge creation, firms should operate according to a decentralised structure, with particular emphasis on developing appropriate platforms and networks for knowledge sharing [7-8]. Social capital has been considered a catalyst for improving knowledge generation and knowledge management. According to Uzzi [8], social capital can derail organisation performance by making firms vulnerable to exogenous shock or insulating them from information effects caused by over-embedded network structure. Reagans \& Zuckerman [9] identified a positive relationship between social capital and productivity. As an organisation nurtures social capital, formal control mechanisms can be replaced by informal control mechanisms [10]. Thus, this study suggests that to create a better environment for knowledge creation, firms should operate in a module of higher delegation of authority, with a special emphasis on social capital and participative management style. Empirical validations related to this research issue are limited and deserve further investigation. 
Finally, researchers on strategic management have contended that knowledge creation and intellectual capital are two key sources of sustainable competitive advantage. According to Wiig [1], intellectual capital management focuses on establishing intellectual assets from the strategic and enterprise governance perspectives. Although many studies have investigated the influence of knowledge-creating activities on knowledge management effectiveness, and also that of business operation mode on organisational performance, few efforts have been made to include the aforementioned three constructs with intellectual capital to discover a more comprehensive knowledge management model. Specifically, the interrelationships among knowledge-creating activities, intellectual capital and knowledge management effectiveness have been subjected to further study. Additionally, the moderating effects of social capital and business operation mode on the relationships between knowledge-creating activities and intellectual capital, which have proved elusive to date, are also within the research scope of this study. Thus, this study aims to first, integrate relevant research constructs into a more comprehensive research framework, and second, carefully investigate the interrelationships among the research constructs. The study results are expected to prove useful to academicians and practitioners in conducting further studies.

\subsection{Research objectives}

Based upon the above research motivations, this study has the following objectives:

- To develop a comprehensive research framework to integrate the interrelationships among knowledge-creating activities, intellectual capital, and knowledge management effectiveness.

- To identify the interrelationships among knowledge-creating activities, intellectual capital and knowledge management effectiveness.

- To examine the influence of social capital and business operation mode on knowledge-creating activities, intellectual capital, and knowledge management effectiveness.

\section{Literature review}

\subsection{Definition of research variables}

\subsubsection{Knowledge-creating activities}

Nonaka \& Takeuchi [11] contended that firm skill and expertise at 'organisational knowledge creation' make a difference in management performance. They argued that organisational knowledge creation represents not only the creation of new knowledge, but also the dissemination and embodiment of this new knowledge. According to them, knowledge can be organised into two distinct categories: tacit and explicit. When tacit and explicit knowledge interact, four modes of knowledge conversion, including socialisation, externalisation, combination and internalisation, constitute the 'engine' of the entire knowledge-creating activity. 


\subsubsection{Intellectual capital}

Previous research has suggested that intellectual capital can be interpreted on either the individual or corporate levels. Adopting an individual approach, Nerdrum \& Erikson [12] conceived intellectual capital as individual complementary capacity to generate added value and thus create wealth. Nevertheless, most researchers have examined this issue from a corporate perspective. Nahapiet \& Ghoshal [13] described intellectual capital as "the knowledge and knowing capability of a social collectivity," while companies in the Intellectual Capital Management Gathering (ICMG) defined intellectual capital as "the sum of a firm's ideas, inventions, technologies, general knowledge, computer programmes, designs, data skills, processes, creativity, and publications."

However, no consensus yet exists regarding the elements of intellectual capital. While Brooking [14] suggested that firm intellectual capital should consist of market assets, human assets, intellectual property assets, and infrastructure assets, Edvinsson \& Malone [15] argued that human capital and structural capital are the most important elements of intellectual capital. Stewart [6] even contended that customer capital should also be included in the scope of intellectual capital, while Bontis et al. [16] proposed that structural capital includes all the non-human storehouses of organisation knowledge, including databases, organisational charts, process manuals, strategies, routines and anything else with a value exceeding its material value. From the above discussion, this study proposed that intellectual capital should be considered a combination of human capital, customer capital, and structural capital.

Marshall [17] emphasised the importance of human assets more than a century ago. Marshall stated that "the most valuable of all capital is that invested in human beings," but never actually used the term 'human capital.' According to Bontis et al. [16], human capital simply represents the individual knowledge residing in an organisation. Every individual in an organisation represents a unit of human capital. St. Onge [18] defined customer capital as comprising four dimensions: depth (penetration), width (coverage), attachment (loyalty), and profitability of corporate operations [5]. Customer capital is the most obvious of intellectual capital, and is relatively easy to track using such indicators as market share, customer retention, and so on.

\subsubsection{Social capital}

Social capital was first adopted in studies of community [19] and family relations, and was then further extended for use in business. Coleman [20] defined social capital as "any aspect of social structure that creates value and facilitates the actions of the individuals within that social structure." Social capital is created when the relations among people change in ways that facilitate instrumental action. Social capital inheres in the relations between and among individuals. Bourdieu \& Wacquant [21] defined social capital more precisely as "the sum of the resources, actual or virtual, that accrue to an individual or a group by virtue of possessing a durable network of more or less institutionalised relationships of mutual acquaintance and recognition." Moreover, Nahapiet \& Ghoshal [13] defined social capital as "the sum of the actual and potential resources embedded within, available through, and derived from the network of relationships possessed by an individual or social unit." Social capital has been proposed to help expedite the efficiency of information diffusion by minimising redundancy [22-23]. Thus, social capital not only reduces transaction costs [24], but also aids adaptive efficiency and associated creativity [13]. Moreover, social capital encourages 
cooperative behaviour, and thus facilitates the development of new forms of association and innovative organisation.

\subsubsection{Business operation mode}

For several decades, researchers have discussed the advantages and disadvantages of decentralised organisations that delegate authority to subordinates. Delegation or participative management style is commonly understood as a process that assigns 'important new tasks' to subordinates, makes them responsible for what previously were management decisions, and gives them authority act without obtaining prior approval [25-26].

Though managers may have to risk the potential mistakes [27], researchers have widely acknowledged the benefits of delegation, namely, organisational flexibility, responsiveness to environmental change [26,28-29]. Previous studies also have suggested that employees in decentralised organisations are more highly motivated, due to their authority to make decisions autonomously [30-31].

\subsubsection{Knowledge management effectiveness}

Effective knowledge management is considered essential to success in modern organisations [32]. It is argued that the effectiveness of knowledge management should be assessed on three levels, namely the corporate, departmental and individual levels. However, this study assessed the effectiveness of knowledge management from both corporate level and individual perspectives.

\subsection{Interrelationships between research constructs}

\subsubsection{Interrelationships among social capital, business operation mode and knowledge-creating activities}

Nahapiet \& Ghoshal [13] stated that the network of relationships possessed by a department enhances knowledge-creating capabilities. Firms with social networks embedded into their operating systems have improved interactions and communications. In such cases, levels of social capital will enhance knowledge creation through discussions and communications among relevant members. Additionally, it is argued that knowledge creation should be exercised under a climate of innovation and information sharing. Thus, if operating under higher levels of delegation of authority with an emphasis on participative operation mode, firms may have more opportunities to create new knowledge or extend existing knowledge through socialisation, externalisation, combination, and internalisation [32]. In other words, firms should employ high delegation of authority while simultaneously emphasising social capital to promote effective knowledge creation and knowledge management. From the above discussion, the first hypothesis is developed as follows: 
H1: Firms with higher levels of participative operations, and higher levels of social capital tend to promote higher levels of knowledge-creating activities, including socialisation, externalisation, combination, and internalisation of knowledge.

\subsubsection{Interrelationships among human capital, customer capital and structural capital}

Previous studies have argued that in a real business operating system, human, structural, and customer capital should work together and support or detract from one another [6]. For example, human capital and structural capital reinforce one another when a company has a shared sense of entrepreneurial spirit and when management highly values agility. On the other hand, human and structural capital could destroy each other when the company does not value the customer and when the corporate centre attempts to control behaviour rather than strategy. Additionally, Bontis et al. [16] have empirically confirmed that human and customer capital are the critical antecedents of structural capital in both service and non-service industries. This study suggests that to develop structural capital, firms should better nurture their human and customer capital.

Previous studies have indicated that among three elements of intellectual capital, human capital is the most significant influence on structural and customer capital. Brooking [14] indicated that managerial skills and leadership styles, which are key components of human capital, and which also influence the accumulation of human capital, enhance intellectual capital. Based upon the above discussions, the second hypothesis is proposed:

\section{H2: Levels of human and customer capital acquired by a firm influence its levels of structural capital.}

\subsubsection{Influence of knowledge-creating activities on intellectual capital}

Previous studies have contended that effective knowledge creation and knowledge management are two main influences on the success of contemporary organisations. Becerra-Fernandez \& Sabherwal [32] proposed that under the focused task domain, internalisation and externalisation of knowledge-creating activities will result in better intellectual capital, and consequently higher effectiveness of knowledge management. Combination and socialisation of knowledge-creating activities are more appropriate for the broad task domain. Furthermore, externalisation and combination are more suitable for content-oriented tasks, while internalisation and socialisation are more appropriate for broad process-oriented tasks. However, knowledge-creating activities enhance the accumulation of intellectual capital in all of the above cases. 
H3: Levels of knowledge-creating activities, including socialisation, externalisation, combination, and internalisation of knowledge, significantly influence the accumulation of firm intellectual capital, including human capital, customer capital, and structural capital.

\subsubsection{Influence of intellectual capital on KM effectiveness}

Naquiyuddin \& Heong [33] posited that knowledge is a necessity that can be applied as a strategic weapon against competitors. An emphasis on knowledge can drive a firm towards a new skill initiative that strives to acquire competitive advantage. Olve et al. [34] argued that intellectual capital is a key element of corporate market value, and once discovered and exploited can provide an organisation with a new resource-base to apply to achieve competitive advantage [35]. Additionally, intellectual capital is the term assigned to the combined intangible assets of markets, intellectual property, human resources and infrastructure, which are essential to firm functioning [14]. Thus, the acquisition of intellectual capital promotes the acquisition of competitive advantage, market value and consequently effective knowledge management. Therefore, from the above statement, this study proposes the fourth hypothesis:

H4: Firm intellectual capital, including human capital, customer capital and structural capital, significantly influences the effectiveness of firm knowledge management.

\subsubsection{Moderating effects of the delegation of authority}

Within the knowledge-based view, individuals develop sequential patters of interaction that enable the integration of specialised knowledge. Previous studies have suggested that such coordination depends heavily on informal procedures in the form of broadly understood roles and interactions established through training and constant repetition [36]. Consequently, to promote intellectual capital and KM effectiveness, a contingency fit is required to enhance knowledge-creating activities under higher levels of authority delegation, with an emphasis on informal procedures. Knowledge-creating activities under informal coordination and participative management style thus result in higher levels of intellectual capital and KM effectiveness. Based upon the above statements, this study proposes the following contingency hypothesis:

H5: Contingency fit between knowledge-creating activities and business operation mode increases the accumulation of firm intellectual capital, including human capital, customer capital, and structural capital.

\subsubsection{Moderating effects of social capital}

Knowledge-creating activities, under the condition of incorporating various social mechanisms and coordination networks into the system influence firm decision to acquire intellectual capital. Previous studies have argued that to promote KM effectiveness, social capital should be embedded within networks of mutual acquaintance and recognition [37]. Ring \& Van de Ven [10] stated that informal control mechanism 
could replace formal control mechanism with continued nurturing of firm social capital. Additionally, Uzzi [8] proposed that an over-embedded network structure makes firms vulnerable to exogenous shock. Only firms that integrate different facets of social capital, namely, trust, interaction and so on, can facilitate knowledge creation and exchange. Therefore, it is essential to have a contingency fit between social capital and knowledge-creating activities to promote intellectual capital and KM effectiveness. From the above statements, we propose the following contingency hypothesis:

H6: The contingency fit between knowledge-creating activities and social capital (i.e. personal trust and interactions of employees), enhances the accumulation of firm intellectual capital, including human capital, customer capital and structural capital.

\section{Research design and methodology}

\subsection{Conceptual model}

This study investigates the interrelationships between knowledge-creating activities, intellectual capital, and KM effectiveness. This study also attempts to verify the moderating effects of social capital and business operation mode on the relationships between knowledge creation and intellectual capital. The following conceptual model was developed for use in this study (see Figure 1).

Figure 1 The conceptual model of this research

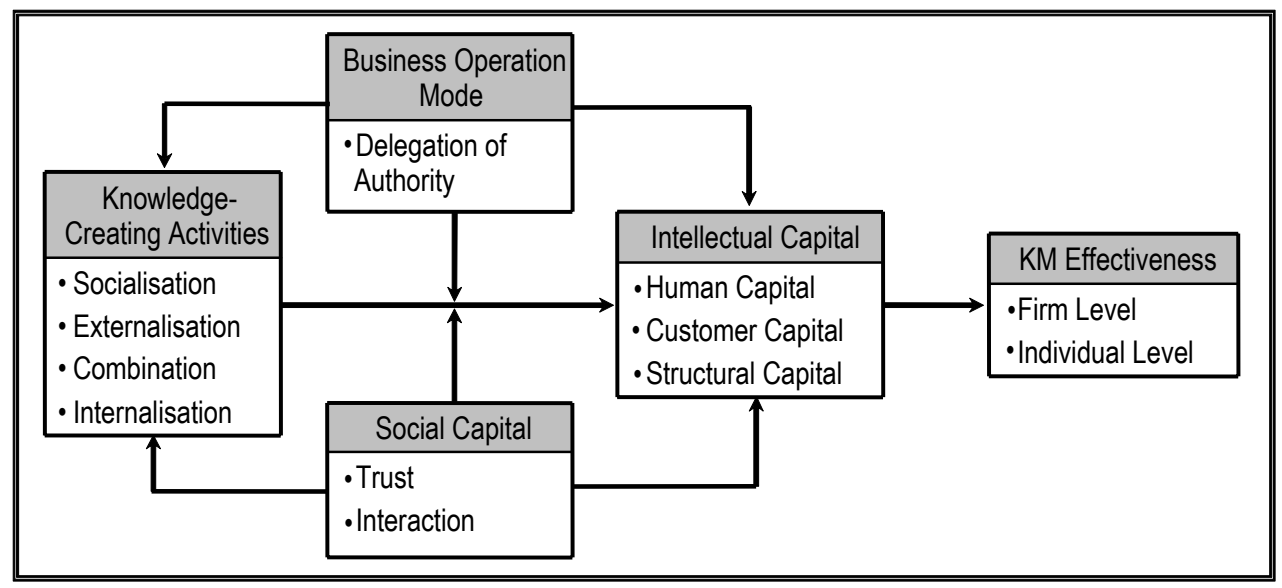

\subsection{Construct measurement}

For this study, five major constructs are operationalised:

1 knowledge-creating activities

2 organisational social capital

3 business operation mode 
4 intellectual capital

5 knowledge management effectiveness.

Table 1 lists the questionnaire items and the results of factor analysis and reliability testing. Following item purification, this study demonstrates that the measurement of the research variables are reliable and suitable for further empirical validation.

Table 1 The results of factor analysis and reliability test

\begin{tabular}{|c|c|c|c|c|}
\hline $\begin{array}{l}\text { Research } \\
\text { construct }\end{array}$ & Research item & $\begin{array}{l}\text { Factor } \\
\text { loading }\end{array}$ & $\begin{array}{c}\text { Item to } \\
\text { total } \\
\text { correlation }\end{array}$ & $\begin{array}{c}\text { Cron } \\
\text { bach's } \\
\alpha\end{array}$ \\
\hline \multirow{21}{*}{$\begin{array}{l}\text { Knowledge- } \\
\text { creating } \\
\text { activities }\end{array}$} & Externalisation & & & .789 \\
\hline & 2. Capture and transfer of experts' knowledge & .856 & .709 & \\
\hline & 1. Modelling based on analogies and metaphors & .766 & .590 & \\
\hline & 3. Artificial intelligence system & .757 & .585 & \\
\hline & 5. Chat groups/web-based discussion groups & 660 & .492 & \\
\hline & 4. Training programme & .647 & .475 & \\
\hline & Combination & & & .750 \\
\hline & 8. Web pages (intranet and internet) & .859 & 643 & \\
\hline & 9. Experts' database & .815 & .570 & \\
\hline & 7. Operational manual & .778 & .524 & \\
\hline & Socialisation & & & .741 \\
\hline & 13. Cooperative projects across units & .860 & 639 & \\
\hline & 11. Brainstorming retreats or camps & .793 & .538 & \\
\hline & 12. Employee rotation across units & .784 & .531 & \\
\hline & Internalisation & & & .767 \\
\hline & 15. On-the-job training & .787 & .593 & \\
\hline & 14. Learning by doing & .764 & .563 & \\
\hline & 16. Learning by observation & .763 & .563 & \\
\hline & 17. Face-to-face meetings & .762 & .561 & \\
\hline & $* 6$. Job-site survey & & DEL & \\
\hline & $\begin{array}{l}* 10 . \text { The use of apprentices and mentors to transfer } \\
\text { knowledge }\end{array}$ & & DEL & \\
\hline \multirow{6}{*}{$\begin{array}{l}\text { Social } \\
\text { capital }\end{array}$} & Social capital & & & .850 \\
\hline & 6. Our colleagues always keep their promises to us & .790 & .696 & \\
\hline & $\begin{array}{l}\text { 9. Our company is characterised by mutual trust among } \\
\text { the colleagues at multiple levels }\end{array}$ & .767 & 672 & \\
\hline & $\begin{array}{l}\text { 5. All the colleagues in our firm share organisational } \\
\text { vision with each other }\end{array}$ & .720 & .613 & \\
\hline & $\begin{array}{l}\text { 8. Our company is characterised by mutual respect } \\
\text { among the colleagues at multiple levels }\end{array}$ & .711 & .604 & \\
\hline & $\begin{array}{l}\text { 7. Our company is characterised by high reciprocity } \\
\text { among the colleagues }\end{array}$ & .707 & .588 & \\
\hline
\end{tabular}


Table 1 The results of factor analysis and reliability test (continued)

\begin{tabular}{|c|c|c|c|c|}
\hline \multirow[t]{6}{*}{$\begin{array}{l}\text { Research } \\
\text { construct }\end{array}$} & Research item & $\begin{array}{c}\text { Factor } \\
\text { loading }\end{array}$ & $\begin{array}{c}\text { Item to } \\
\text { total } \\
\text { correlation }\end{array}$ & $\begin{array}{c}\text { Cron } \\
\text { bach's } \\
\alpha\end{array}$ \\
\hline & $\begin{array}{l}\text { 4. I will not take advantage of others when the } \\
\text { opportunity arises }\end{array}$ & .679 & .561 & \\
\hline & $\begin{array}{l}\text { 1. I maintain close social relationships with our } \\
\text { colleagues }\end{array}$ & .633 & .523 & \\
\hline & $\begin{array}{l}\text { 10. Our company is characterised by personal friendship } \\
\text { among the colleagues at multiple levels }\end{array}$ & .608 & .484 & \\
\hline & $\begin{array}{l}* 2 \text {. I spend a lot of time in social interaction with our } \\
\text { colleagues }\end{array}$ & & DEL & \\
\hline & *3. I know our colleagues on a personal level & & & \\
\hline \multirow{7}{*}{$\begin{array}{l}\text { Business } \\
\text { operation } \\
\text { mode }\end{array}$} & Delegation of authority & & & .840 \\
\hline & $\begin{array}{l}\text { 6. Managers delegate little authority to their } \\
\text { subordinates }\end{array}$ & .909 & .776 & \\
\hline & 1. Our organisation is highly centralised & .899 & .779 & \\
\hline & 5. Managers seldom inquire subordinates' opinion & .847 & .694 & \\
\hline & 2. Working projects are closely monitored & .626 & .470 & \\
\hline & $* 3$. We have very detailed manuals and regulations & & DEL & \\
\hline & $\begin{array}{l}\text { *4. We often communicate and give/receive order } \\
\text { through formal paperwork. }\end{array}$ & & DEL & \\
\hline \multirow{13}{*}{$\begin{array}{l}\text { Human } \\
\text { capital }\end{array}$} & Human capital & & & .957 \\
\hline & 7. Our employees consistently perform at their best & .908 & .881 & \\
\hline & $\begin{array}{l}\text { 6. Our employees are widely considered as the best in } \\
\text { the whole industry }\end{array}$ & .896 & .867 & \\
\hline & $\begin{array}{l}\text { 5. The creativity of our employees has improved } \\
\text { significantly }\end{array}$ & .886 & .854 & \\
\hline & 8. Individuals learn form each other & .867 & .834 & \\
\hline & $\begin{array}{l}\text { 9. Employees are excited to voice their opinions with } \\
\text { their colleagues }\end{array}$ & .849 & .811 & \\
\hline & $\begin{array}{l}\text { 10. Our employees generally give it their all to make } \\
\text { this firm different from the others in the industry }\end{array}$ & .839 & .800 & \\
\hline & $\begin{array}{l}\text { 4. The firm supports our employees by constantly } \\
\text { upgrading their skills and education whenever each of } \\
\text { them feels it is necessary }\end{array}$ & .838 & .797 & \\
\hline & $\begin{array}{l}\text { 3. Our organisation consistently comes up with great } \\
\text { new ideas }\end{array}$ & .824 & .781 & \\
\hline & $\begin{array}{l}\text { 1. The competence of our employees as a whole is equal } \\
\text { to the most ideal level we could ever hope to achieve }\end{array}$ & .811 & .765 & \\
\hline & $\begin{array}{l}\text { 2. The relationships between various departments are } \\
\text { getting closer }\end{array}$ & .799 & .750 & \\
\hline & Customer capital & & & .937 \\
\hline & $\begin{array}{l}\text { 7. We continually meet with customers to find out what } \\
\text { they want from us }\end{array}$ & .874 & .836 & \\
\hline
\end{tabular}


Table 1 The results of factor analysis and reliability test (continued)

\begin{tabular}{|c|c|c|c|c|}
\hline $\begin{array}{l}\text { Research } \\
\text { construct }\end{array}$ & Research item & $\begin{array}{c}\text { Factor } \\
\text { loading }\end{array}$ & $\begin{array}{c}\text { Item to } \\
\text { total } \\
\text { correlation }\end{array}$ & $\begin{array}{c}\text { Cron } \\
\text { bach's } \\
\alpha\end{array}$ \\
\hline \multirow{11}{*}{$\begin{array}{l}\text { Customer } \\
\text { capital }\end{array}$} & $\begin{array}{l}\text { 11. We feel confident that our customers will continue to } \\
\text { do business with us }\end{array}$ & .864 & .823 & \\
\hline & $\begin{array}{l}\text { 4. Our organisation thrives on maintaining the most } \\
\text { positive value-added service of any firm in the industry }\end{array}$ & .826 & .783 & \\
\hline & $\begin{array}{l}\text { 1. A poll of our customers would indicate that they are } \\
\text { generally satisfied with our organisation }\end{array}$ & .818 & .771 & \\
\hline & 6. Our organisation prides itself on being market-oriented & .809 & .767 & \\
\hline & $\begin{array}{l}\text { 2. We have greatly reduced the time it takes to resolve a } \\
\text { customer's problem }\end{array}$ & .801 & .753 & \\
\hline & $\begin{array}{l}\text { 10. We capitalise on our customers' wants and needs by } \\
\text { continually striving to make them satisfied }\end{array}$ & .774 & .711 & \\
\hline & $\begin{array}{l}\text { 5. Our customer are loyal to our company, more so than } \\
\text { to any other in the industry }\end{array}$ & .773 & .697 & \\
\hline & $\begin{array}{l}\text { 12. We get as much feedback out of our customers as we } \\
\text { possibly can under the circumstances }\end{array}$ & .753 & .719 & \\
\hline & 3. Our market share is the highest in the industry & .743 & .689 & \\
\hline & $\begin{array}{l}\text { 8. Data on customer feedback is disseminated throughout } \\
\text { the organisation }\end{array}$ & .700 & .637 & \\
\hline & $\begin{array}{l}* 9 . \text { We generally do not care about what the customer } \\
\text { thinks or wants from us }\end{array}$ & & DEL & \\
\hline \multirow{12}{*}{$\begin{array}{l}\text { Structural } \\
\text { capital }\end{array}$} & Structural capital & & & .927 \\
\hline & 5. We implement a large portion of our great new ideas & .891 & .851 & \\
\hline & $\begin{array}{l}\text { 6. Our company supports the development of new ideas } \\
\text { and products }\end{array}$ & .859 & .808 & \\
\hline & $\begin{array}{l}\text { 4. The time it takes to complete one whole transaction is } \\
\text { the best in the industry }\end{array}$ & .809 & .742 & \\
\hline & 8. Our organisation prides itself on being efficient & .797 & .758 & \\
\hline & $\begin{array}{l}\text { 10. The systems and procedures of our organisation } \\
\text { support innovation }\end{array}$ & .787 & .729 & \\
\hline & $\begin{array}{l}\text { 7. Our company develops more new ideas and products } \\
\text { than any other firm in the industry }\end{array}$ & .776 & .710 & \\
\hline & $\begin{array}{l}\text { 11. Our organisation's culture and atmosphere is } \\
\text { supportive and comfortable }\end{array}$ & .772 & .716 & \\
\hline & $\begin{array}{l}\text { 9. Our data systems make it easy to access relevant } \\
\text { information }\end{array}$ & .738 & .675 & \\
\hline & $\begin{array}{l}\text { 2. We have continually been improving our costs per } \\
\text { revenue dollar }\end{array}$ & .718 & .651 & \\
\hline & $\begin{array}{l}\text { 3. The time it takes to complete one whole transaction has } \\
\text { been decreasing over the past few years }\end{array}$ & .639 & .564 & \\
\hline & $\begin{array}{l}* 1 \text {. Our organisation has the lowest costs per transaction } \\
\text { of any in the industry }\end{array}$ & & DEL & \\
\hline
\end{tabular}


Table 1 The results of factor analysis and reliability test (continued)

\begin{tabular}{|c|c|c|c|c|}
\hline $\begin{array}{l}\text { Research } \\
\text { construct }\end{array}$ & Research item & $\begin{array}{l}\text { Factor } \\
\text { loading }\end{array}$ & $\begin{array}{c}\text { Item to } \\
\text { total } \\
\text { correlation }\end{array}$ & $\begin{array}{c}\text { Cron } \\
\text { bach's } \\
\alpha\end{array}$ \\
\hline \multirow{8}{*}{$\begin{array}{l}\text { KM } \\
\text { effectiveness }\end{array}$} & KM effectiveness & & & .946 \\
\hline & $\begin{array}{l}\text { 6. The available knowledge improves my company's } \\
\text { overall effectiveness }\end{array}$ & .904 & .864 & \\
\hline & $\begin{array}{l}\text { 4. We are satisfied with the knowledge available for } \\
\text { various tasks across our company }\end{array}$ & .897 & .854 & \\
\hline & $\begin{array}{l}\text { 3. We are satisfied with the management of knowledge } \\
\text { we need }\end{array}$ & .895 & .851 & \\
\hline & $\begin{array}{l}\text { 2. The available knowledge improves our effectiveness } \\
\text { in performing our tasks }\end{array}$ & .881 & .833 & \\
\hline & $\begin{array}{l}\text { 7. We are satisfied with the management of knowledge } \\
\text { at our company }\end{array}$ & .848 & .792 & \\
\hline & $\begin{array}{l}\text { 1. We are satisfied with the availability of knowledge } \\
\text { for our tasks }\end{array}$ & .834 & .775 & \\
\hline & $\begin{array}{l}\text { 5. We are satisfied with knowledge sharing among } \\
\text { colleagues at our company }\end{array}$ & .828 & .766 & \\
\hline
\end{tabular}

Note: The questionnaire items with asterisk are not reliable and thus delete from further analysis

\subsection{Questionnaire design}

As discussed above, an 82-item survey questionnaire was developed to obtain responses from high, middle, and low level managers/supervisors regarding their opinions on various variables. The questionnaire administered in this study contains five sections: 'knowledge-creating activities (17 items),' 'social capital (ten items),' 'business operation mode (six items),' 'intellectual capital (including 11 items on structural capital, 12 items on customer capital, and ten items on human capital),' 'knowledge management effectiveness (seven items),' 'firm characteristics (four items),' and 'respondent characteristics (five items).'

The authors first designed a preliminary version of the above questionnaire. An expert interview then was conducted to examine whether the questionnaire items fitted the actual knowledge management operations of the firms. Subsequently, the questionnaire was pretested via a pilot study by EMBA students in a major public university in Taiwan. Finally, questionnaire items were revised based upon the results of the pilot study before developing the final version.

\subsection{Sampling plan}

A sampling plan was developed to ensure that this study focused on certain types of firms. This study sampled companies in Taiwan that had implemented and adopted KM programmes. The sample companies were obtained from 'The 2000 Largest Corporations in Taiwan (2002),' published by the China Credit Information Service, Ltd. 


\section{Research results and analysis}

\subsection{Descriptive analysis}

The data was gathered over a three-month period from the middle of January, 2003 to the end of April, 2003, and included one pilot test and one final survey. A total of 1,000 survey questionnaires were mailed to the sample firms for the final survey. Out of 1000 sample firms, 144 completed and returned the surveys, after follow-up telephone calls being made to all firms to remind them of the survey. A total of 134 of the returned questionnaires were usable, producing a final response rate of $13.4 \%$.

Table 2 lists the basic attributes of the sample firms. This table reveals that over $50 \%$ of respondents belong to the non-manufacturing sector. Moreover, over $51 \%$ of the respondent firms had been operating for less than 20 years. Over $56 \%$ of the firms had annual revenue of 500 million NT dollars or above. Finally, more than $50 \%$ of the sampled firms had less than 1,500 company employees.

Table 2 The characteristics of sample firms

\begin{tabular}{lcc}
\hline & Frequency & Percentage (\%) \\
\hline & Industry & 41 \\
Manufacturer & 55 & 59 \\
Non-manufacturer & 79 & \\
& History & 22.4 \\
Less than ten years & 30 & 29.1 \\
11 to 20 years & 39 & 12.7 \\
21 to 30 years & 17 & 17.2 \\
31 to 40 years & 23 & 18.7 \\
More than 40 years & 25 & \\
& Annual revenue & 14.9 \\
Less than 50 millions & 50 & 24.7 \\
51 to 500 millions & 33 & 56.7 \\
More than 500 millions & 76 & \\
& Number of employees & 50.0 \\
Less than 1500 & 67 & 18.7 \\
1500 to 5000 & 25 & 14.9 \\
5001 to 10000 & 20 & 15.7 \\
More than 10000 & 21 & \\
\hline
\end{tabular}




\subsection{Interrelationships among social capital, delegation of authority, and knowledge-creating activities}

For relationships between social capital and knowledge-creating activities, the results of canonical correlation demonstrate that the levels of indicators of social capital tend to significantly influence externalisation, combination, socialisation, and internalisation of knowledge creation $\left(\mathrm{Can} \mathrm{R}^{2}=0.403, \mathrm{~F}=3.141, \mathrm{P}=0.000, \mathrm{RI}=14.139 \%\right.$ ). Additionally, the study results also show that the levels of indicators of social capital tend to significantly influence levels of authority delegation (Can $\mathrm{R}^{2}=0.147, \mathrm{~F}=1.740$, $\mathrm{P}=0.038$, RI $=8.092 \%$ ). Furthermore, levels of authority delegation in a firm tend to influence externalisation, combination, socialisation and internalisation of knowledge creation $\left(\mathrm{Can} \mathrm{R}^{2}=0.282, \mathrm{~F}=2.264, \mathrm{P}=0.000, \mathrm{RI}=18.438\right)$.

Figure 2 and Table 3 illustrate the detailed information of canonical correlation. These results agree with those of previous studies [14,31,36]. Bourdieu [36] and Nahapiet \& Ghoshal [14] all contend that to promote KM effectiveness, social capital should be embedded with networks of mutual acquaintance and recognition. Knowledge creation under higher socialised communication and coordination generally increases KM effectiveness. Thus, social capital, delegation of authority, and knowledge creation are significantly and closely related. Firms wishing to promote knowledge creation should expend increased efforts on creating an organisational climate that provides higher levels of social capital and delegation of authority, with a participative management style. The above findings support Hypothesis 1.

Figure 2 The interrelationships between social capital, delegation of authority, and knowledge management effectiveness

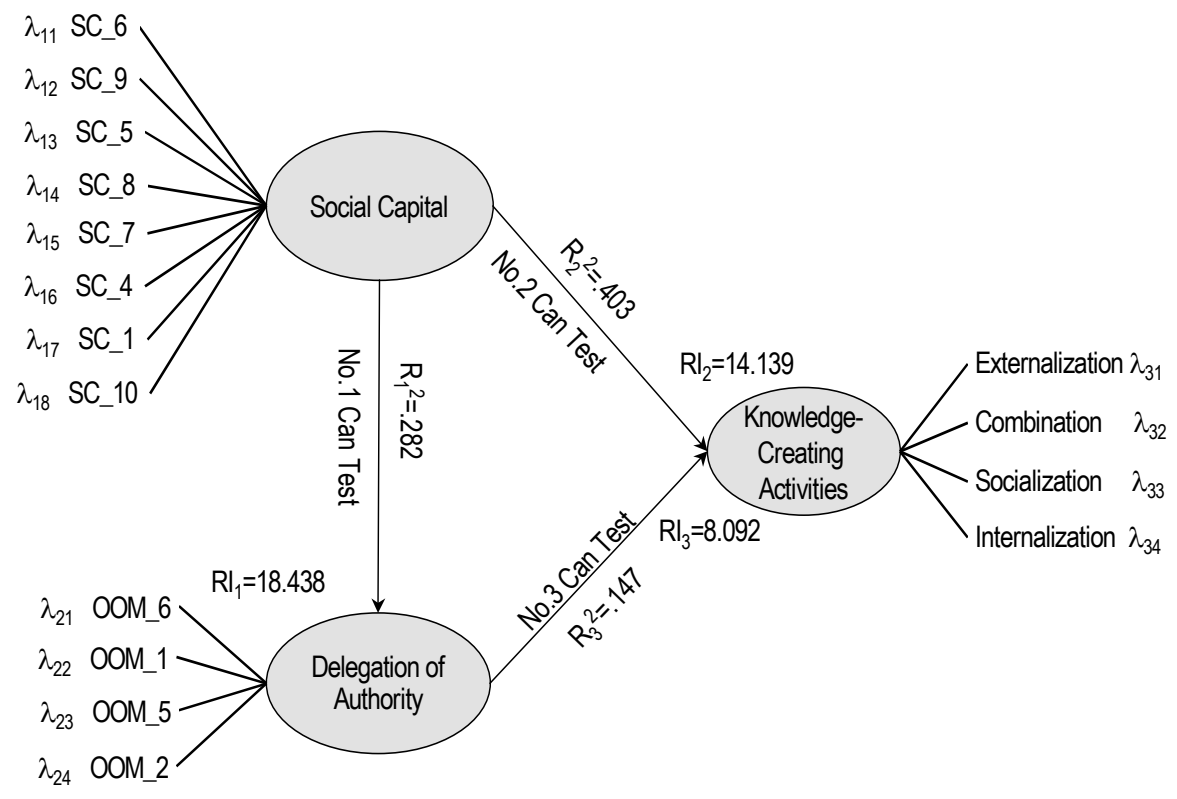


Table 3 The canonical correlation analysis results of social capital, authority delegation, and knowledge creation activities

\begin{tabular}{lcc}
\hline \multicolumn{3}{c}{ Canonical loadings } \\
\hline SC $\leftarrow \rightarrow$ Delegation & $S C \leftarrow \rightarrow$ KCA & Delegation $\leftarrow \rightarrow K C A$ \\
No. 1 canonical test & No. 2 canonical test & No. 3 canonical test \\
\hline$\lambda_{11}=.452^{*}$ & $\lambda_{11}=.610^{*}$ & $\lambda_{21}=.766^{*}$ \\
$\lambda_{12}=.606^{*}$ & $\lambda_{12}=.462^{*}$ & $\lambda_{22}=.991^{*}$ \\
$\lambda_{13}=.484^{*}$ & $\lambda_{13}=.750^{*}$ & $\lambda_{23}=.679^{*}$ \\
$\lambda_{14}=.498^{*}$ & $\lambda_{14}=.492^{*}$ & $\lambda_{24}=.420^{*}$ \\
$\lambda_{15}=.753^{*}$ & $\lambda_{15}=.574^{*}$ & $\lambda_{31}=.948^{*}$ \\
$\lambda_{16}=.520^{*}$ & $\lambda_{16}=.322^{*}$ & $\lambda_{32}=.588^{*}$ \\
$\lambda_{17}=.094$ & $\lambda_{17}=.608^{*}$ & $\lambda_{33}=.576^{*}$ \\
$\lambda_{18}=.535^{*}$ & $\lambda_{18}=.786^{*}$ & $\lambda_{34}=.678^{*}$ \\
$\lambda_{21}=.964^{*}$ & $\lambda_{31}=.935^{*}$ & \\
$\lambda_{22}=.857^{*}$ & $\lambda_{32}=.748^{*}$ & \\
$\lambda_{23}=.869^{*}$ & $\lambda_{33}=.774^{*}$ & \\
$\lambda_{24}=.441^{*}$ & $\lambda_{34}=.735^{*}$ & \\
\hline
\end{tabular}

\subsection{Interrelationships among structural capital, human capital, and customer capital}

The results of canonical correlation between human capital and customer capital show that the levels of indicators for human capital tend to significantly influence all indicators of customer capital $\left(\mathrm{Can} \mathrm{R}^{2}=0.541, \mathrm{~F}=2.015, \mathrm{P}=0.000, \mathrm{RI}=36.494 \%\right)$. Additionally, the results demonstrate that indicators of human capital tend to significantly influence organisational structural capital $\left(\mathrm{Can} \mathrm{R}^{2}=0.718, \mathrm{~F}=2.976, \mathrm{P}=0.000, \mathrm{RI}=49.204 \%\right)$. Furthermore, the canonical correlation results also suggest that customer capital significantly impacts structural capital $\left(\mathrm{Can} \mathrm{R}^{2}=0.637, \mathrm{~F}=2.556, \mathrm{P}=0.000\right.$, $\mathrm{RI}=36.265 \%)$.

Figure 3 and Table 4 show detailed information on canonical correlation. The results listed in the tables are in line with those of previous studies [6,16]. Stewart [6] argued that in a real business operation system, human, customer, and structural capital should cooperate and work together. Bontis et al. [16] further noted that human capital and customer capital could serve as the antecedents of structural capital. Thus, significant interrelationships exist among human capital, customer capital and structural capital. Firms intending to promote structural capital should increase their efforts to develop organisational human capital and customer capital. The above result supports Hypothesis 2. 
Figure 3 The interrelationships between human capital, customer capital, and structural capital

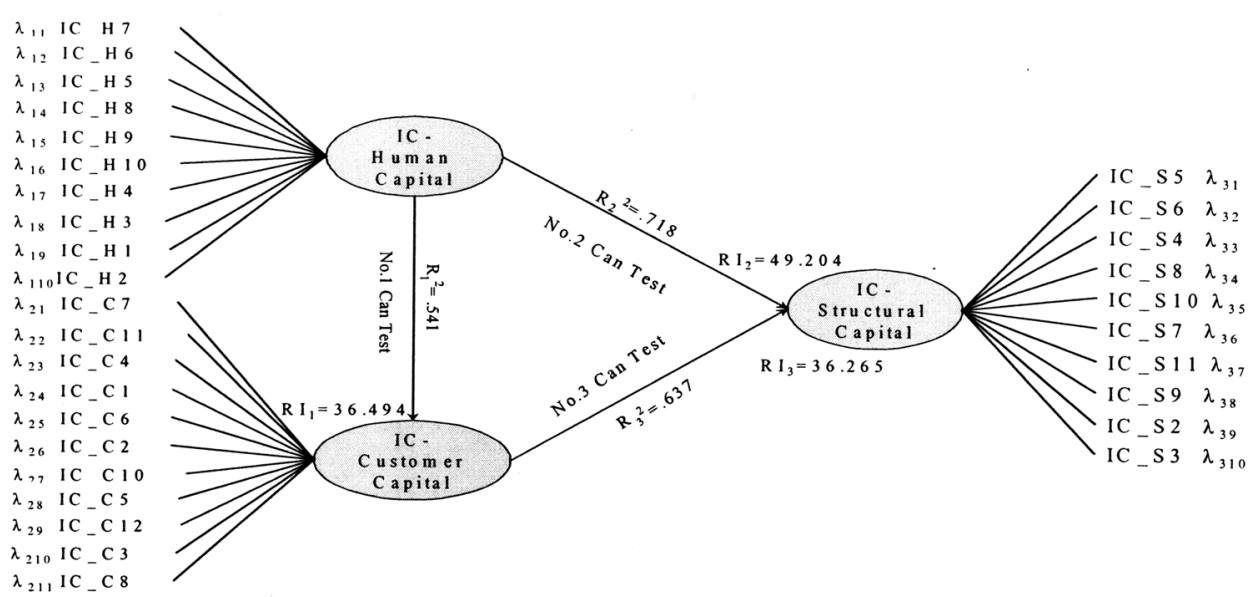

Table 4 The canonical correlation analysis results of human capital, customer capital, and structural capital

\begin{tabular}{lcc}
\hline & Canonical loadings & \\
\hline$H C \leftarrow \rightarrow C C$ & $H C \leftarrow \rightarrow S C$ & $C C \leftarrow \rightarrow S C$ \\
No.1 canonical test & No. 2 canonical test & No. 3 canonical test \\
\hline$\lambda 11=.812^{*}$ & $\lambda 11=.873^{*}$ & $\lambda 21=.745^{*}$ \\
$\lambda 12=.884$ & $\lambda 12=.818^{*}$ & $\lambda 22=.768^{*}$ \\
$\lambda 13=.848^{*}$ & $\lambda 13=.811^{*}$ & $\lambda 23=.863^{*}$ \\
$\lambda 14=.752^{*}$ & $\lambda 14=.802^{*}$ & $\lambda 24=.680^{*}$ \\
$\lambda 15=.778^{*}$ & $\lambda 15=.806^{*}$ & $\lambda 25=.843^{*}$ \\
$\lambda 16=.811^{*}$ & $\lambda 16=.879^{*}$ & $\lambda 26=.767^{*}$ \\
$\lambda 17=.844^{*}$ & $\lambda 17=.795^{*}$ & $\lambda 27=.736^{*}$ \\
$\lambda 18=.874^{*}$ & $\lambda 18=.828^{*}$ & $\lambda 28=.701^{*}$ \\
$\lambda 19=.828^{*}$ & $\lambda 19=.852^{*}$ & $\lambda 29=.672^{*}$ \\
$\lambda 110=.774^{*}$ & $\lambda 110=.811^{*}$ & $\lambda 210=.823^{*}$ \\
$\lambda 21=.847^{*}$ & $\lambda 31=.825^{*}$ & $\lambda 211=.668^{*}$ \\
$\lambda 22=.776^{*}$ & $\lambda 32=.785^{*}$ & $\lambda 31=.880^{*}$ \\
$\lambda 23=.827^{*}$ & $\lambda 33=.623^{*}$ & $\lambda 32=.835^{*}$ \\
$\lambda 24=.726^{*}$ & $\lambda 34=.819^{*}$ & $\lambda 33=.727^{*}$ \\
$\lambda 25=.784^{*}$ & $\lambda 35=.820^{*}$ & $\lambda 34=.862^{*}$ \\
$\lambda 26=.794^{*}$ & $\lambda 36=.634^{*}$ & $\lambda 35=.776^{*}$ \\
$\lambda 27=.772^{*}$ & $\lambda 37=.96^{*}$ & $\lambda 36=.797^{*}$ \\
$\lambda 28=.804^{*}$ & $\lambda 38=.673^{*}$ & $\lambda 37=.744^{*}$ \\
\hline
\end{tabular}


Table 4 The canonical correlation analysis results of human capital, customer capital, and structural capital (continued)

\begin{tabular}{lcc}
\hline \multicolumn{3}{c}{ Canonical loadings } \\
\hline$H C \leftarrow \rightarrow C C$ & $H C \leftarrow \rightarrow S C$ & $C C \leftarrow \rightarrow S C$ \\
No.1 canonical test & No. 2 canonical test & No. 3 canonical test \\
\hline$\lambda 29=.689^{*}$ & $\lambda 39=.625^{*}$ & $\lambda 38=.716^{*}$ \\
$\lambda 210=.636^{*}$ & $\lambda 310=.395^{*}$ & $\lambda 39=.706^{*}$ \\
$\lambda 211=.755^{*}$ & & $\lambda 310=.635^{*}$ \\
\hline
\end{tabular}

\subsection{Structural equation model}

This study identifies the relationships among knowledge-creating activities, social capital, delegation of authority, intellectual capital, and knowledge management effectiveness. To achieve this objective, structural equation model is employed to test the interrelationships among research constructs of all the model variables. Figure 4 illustrates the proposed structural equation model.

Figure 4 Structural equation model of this study

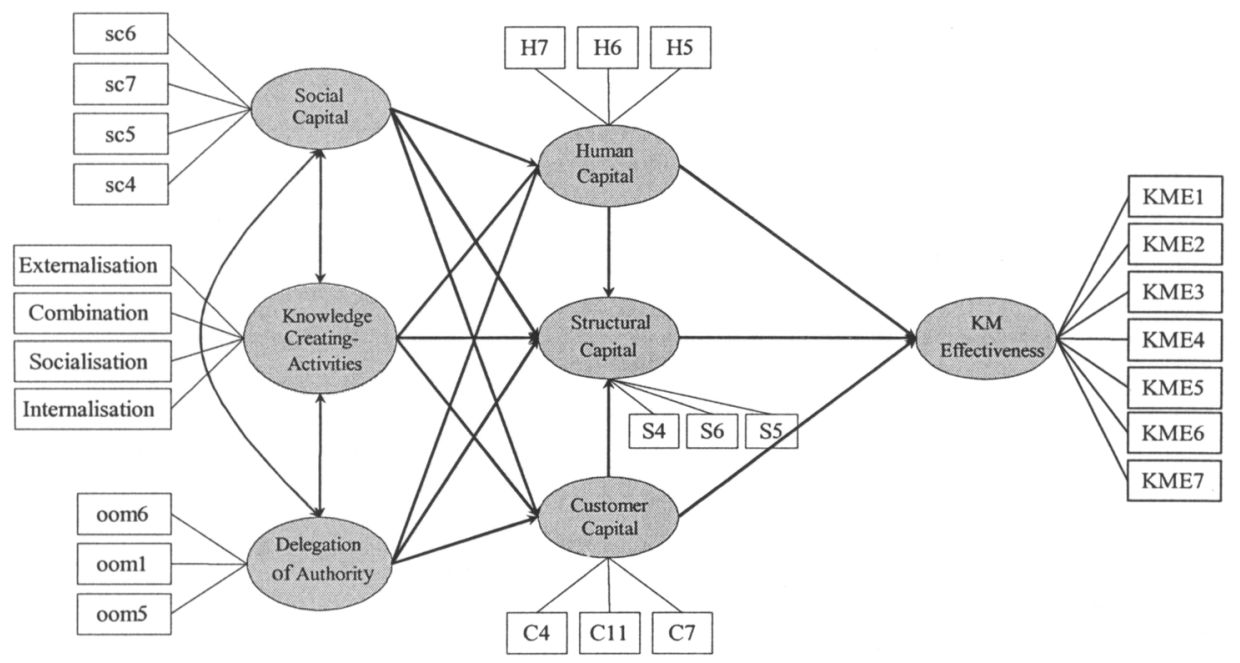

Before evaluating the structural or measurement models, the overall model fit must be assessed to ensure that the model adequately represents the entire set of causal relationships. Based on the approach of Arbuckle \& Worthke [38] and Vigoda [39], this study uses chi-square, goodness of fit index (GFI), adjusted goodness of fit index (AGFI) and root mean square residual (RMR) to evaluate overall model fit.

The chi-square test is essential for nested model comparison with this model. The chi-square value of 417.818 with 305 degrees of freedom is statistically significant at the 0.000 significance level. Since the small sample size of 134 does not adversely affect the sensitivity of this measure, significant differences must be recognised. However, this study also notes that the chi-square test becomes more sensitive with increasing number 
of indicators. Joreskog \& Sorbom [40] suggested that the ratio of chi-square value to degree of freedom should not exceed three. A chi-square/df $=1.370$ appears acceptable. Bearing this in mind, other measures will also be examined.

Model fit improves with decreasing RMR. This study defines a RMR of 0.05 as a close fit [38-39]. GFI and AGFI are not explicitly influenced by sample size, and test the degree to which the model fits better than the null model. A very good research model fit is defined as GFI and AGFI exceeding 0.9 [38-39]. The quality of the apriori alternative models should depend on the fit indices. However, it does not necessarily mean that one model is superior to alternatives, or is the optimum causal model. Another important criterion for model quality is the plausibility criterion [40]. This criterion means that the path coefficients in the model adhere to the general theoretical conception and our hypotheses. Therefore, a model that fits the data well but contains many unsupported hypothesised paths cannot be considered correct.

Based on the above criteria, the best model (see Figure 4) is tested in this study. Table 5 lists the estimated model fit indices, and demonstrates a large and significant chi-square (417.8), with GFI of 0.906 , and AGFI of 0.883 . These fit indices indicate moderate model fit.

Table 5 The results of structure equation model

\begin{tabular}{|c|c|c|c|c|}
\hline & \multicolumn{2}{|c|}{ Relations } & \multirow{2}{*}{$\begin{array}{c}\begin{array}{c}\text { Standardised } \\
\text { coefficients }\end{array} \\
.702 *\end{array}$} & \multirow{2}{*}{$\begin{array}{c}C . R . \\
\mathrm{a}\end{array}$} \\
\hline \multirow{20}{*}{ Variables } & \multirow{4}{*}{ Social capital } & SC6 & & \\
\hline & & SC7 & $.524 *$ & 7.710 \\
\hline & & SC5 & $.821 *$ & 7.302 \\
\hline & & SC4 & $.626 *$ & 6.157 \\
\hline & \multirow{4}{*}{ Knowledge-creating activities } & Externalisation & $.869 *$ & $\mathrm{a}$ \\
\hline & & Combination & $.790 *$ & 10.423 \\
\hline & & Socialisation & $.683 *$ & 8.565 \\
\hline & & Internalisation & $.657 *$ & 8.131 \\
\hline & \multirow{3}{*}{ Delegation of authority } & OOM6 & $.935 *$ & $\mathrm{a}$ \\
\hline & & OOM1 & $.829 *$ & 12.302 \\
\hline & & OOM5 & $.791 *$ & 11.430 \\
\hline & \multirow{3}{*}{ Human capital } & IC-H7 & $.918 *$ & $\mathrm{a}$ \\
\hline & & IC-H6 & $.919 *$ & 17.513 \\
\hline & & IC-H5 & $.879 *$ & 15.764 \\
\hline & \multirow{3}{*}{ Customer capital } & IC-C4 & $.755 *$ & $\mathrm{a}$ \\
\hline & & IC-C11 & $.858 *$ & 10.106 \\
\hline & & IC-C7 & $.892 *$ & 10.511 \\
\hline & \multirow{3}{*}{ Structural capital } & IC-S4 & $.723 *$ & $\mathrm{a}$ \\
\hline & & IC-S6 & $.921 *$ & 10.363 \\
\hline & & IC-S5 & $.929 *$ & 10.436 \\
\hline
\end{tabular}


Table 5 The results of structure equation model (continued)

\begin{tabular}{|c|c|c|c|c|}
\hline & \multicolumn{2}{|c|}{ Relations } & $\begin{array}{c}\text { Standardised } \\
\text { coefficients }\end{array}$ & C. $R$. \\
\hline & \multirow{7}{*}{$\begin{array}{l}\text { Knowledge management } \\
\text { effectiveness }\end{array}$} & KME1 & $.817 *$ & a \\
\hline & & KME2 & $.855 *$ & 11.889 \\
\hline & & KME3 & $.872 *$ & 12.257 \\
\hline & & KME4 & $.872 *$ & 12.250 \\
\hline & & KME5 & $.787 *$ & 10.523 \\
\hline & & KME6 & $.902 *$ & 11.219 \\
\hline & & KME7 & $.825 *$ & 11.261 \\
\hline \multirow{17}{*}{ Paths } & \multicolumn{2}{|c|}{ Social capital $<->$ delegation of authority $\left(\rho_{1}\right)$} & $0.358 *$ & 3.176 \\
\hline & \multicolumn{2}{|c|}{ Social capital $<->$ knowledge-creating activities $\left(\rho_{2}\right)$} & $0.552 *$ & 4.283 \\
\hline & \multicolumn{2}{|c|}{$\begin{array}{l}\text { Delegation of authority }<->\text { knowledge-creating } \\
\text { activities }\left(\rho_{3}\right)\end{array}$} & $0.342 *$ & 3.315 \\
\hline & \multicolumn{2}{|c|}{ Knowledge-creating activities $->$ human capital $\left(\gamma_{1}\right)$} & $0.495 *$ & 5.288 \\
\hline & \multicolumn{2}{|c|}{ Delegation of authority $->$ human capital $\left(\gamma_{2}\right)$} & $0.168 *$ & 2.290 \\
\hline & \multicolumn{2}{|c|}{ Social capital $->$ human capital $\left(\gamma_{3}\right)$} & $0.291 *$ & 2.984 \\
\hline & \multicolumn{2}{|c|}{ Knowledge-creating activities $->$ customer capital $\left(\gamma_{4}\right)$} & $0.274 *$ & 2.565 \\
\hline & \multicolumn{2}{|c|}{ Delegation of authority $->$ customer capital $\left(\gamma_{5}\right)$} & $0.279 *$ & 3.128 \\
\hline & \multicolumn{2}{|c|}{ Social capital $->$ customer capital $\left(\gamma_{6}\right)$} & $0.292 *$ & 2.534 \\
\hline & \multicolumn{2}{|c|}{ Knowledge-creating activities $->$ structural capital $\left(\gamma_{7}\right)$} & $0.237 *$ & 2.101 \\
\hline & \multicolumn{2}{|c|}{ Delegation of authority $->$ structural capital $\left(\gamma_{8}\right)$} & 0.003 & 0.040 \\
\hline & \multicolumn{2}{|c|}{ Social capital - > structural capital $\left(\gamma_{9}\right)$} & 0.158 & 1.476 \\
\hline & \multicolumn{2}{|c|}{ Human capital $->$ structural capital $\left(\beta_{1}\right)$} & 0.147 & 1.272 \\
\hline & \multicolumn{2}{|c|}{ Customer capital $->$ structural capital $\left(\beta_{2}\right)$} & $0.395 *$ & 3.823 \\
\hline & \multicolumn{2}{|c|}{ Human capital $->$ KM effectiveness $\left(\beta_{3}\right)$} & $0.592 *$ & 6.540 \\
\hline & \multicolumn{2}{|c|}{ Customer capital $->\mathrm{KM}$ effectiveness $\left(\beta_{4}\right)$} & $0.196 *$ & 2.091 \\
\hline & \multicolumn{2}{|c|}{ Structural capital -> KM effectiveness $\left(\beta_{5}\right)$} & 0.100 & 0.995 \\
\hline \multirow{6}{*}{ Fit index } & \multicolumn{2}{|c|}{ Chi-square } & \multicolumn{2}{|c|}{$417.818(\mathrm{P}=0.000)$} \\
\hline & \multicolumn{2}{|c|}{ Degree of freedom (d. f.) } & \multicolumn{2}{|c|}{305} \\
\hline & \multicolumn{2}{|c|}{ Chi-square/d. f. } & \multicolumn{2}{|c|}{1.370} \\
\hline & \multicolumn{2}{|c|}{ GFI } & \multicolumn{2}{|c|}{0.906} \\
\hline & \multicolumn{2}{|c|}{ AGFI } & 0. & \\
\hline & & & 0. & \\
\hline
\end{tabular}

Note: $\quad 1$ *: C. R. > 1.96; using a significance level of 0.05 , critical ratios that exceed 1.96 are significant

2. a: the parameter compared by others is set as 1 , therefore there is no C. R.. It is determined as significant 
Since the model has promising overall goodness of fit, the study further identify the magnitudes and significance of the path structural coefficients of the model. The analytical results indicate that knowledge-creating activities, delegation of authority (participative operation mode) and social capital of a firm significantly influence human capital $\left(\gamma_{1}=0.495, \gamma_{2}=0.168, \gamma_{3}=0.291\right)$ and customer capital $\left(\gamma_{4}=0.274, \gamma_{5}=0.279\right.$, $\left.\gamma_{6}=0.292\right)$. Although knowledge-creating activities significantly influence structural capital $(\gamma=0.237)$, no significant relationships exist among delegation of authority, social capital and structural capital $\left(\gamma_{8}=0.003, \gamma_{9}=0.158\right)$. Firm human capital and customer capital positively influence knowledge management effectiveness $\left(\beta_{3}=0.592\right.$, $\left.\beta_{4}=0.196\right)$.

To summarise, the model has acceptable goodness of fit and appears to suggest that to enhance intellectual capital, firms should implement high delegation of authority, with an emphasis on the accumulation of social capital. Under such an operation mode, firms can promote more knowledge-creating activities and increase their levels of intellectual capital, including human capital, customer capital and structural capital. It is suggested that only firms with higher intellectual capital can acquire more effective knowledge management.

The above findings agree with those of Becerra-Fernandez \& Sabherwal [32]. Becerra-Fernandez \& Sabherwal proposed that firms can better accumulate intellectual capital and achieve effective knowledge management through knowledge-creating activities, namely, externalisation, combination, socialisation and internalisation of knowledge.

\subsection{Comparisons of research factors between firms with different levels of social capital}

Previous studies have demonstrated that levels of social capital and delegation of authority can enhance knowledge-creating activities and increase intellectual capital. This study applies cluster analysis to identify the moderating effects of social capital and delegation of authority on knowledge-creating activities and intellectual capital, respectively.

Table 6 lists the influences of social capital on factors related to knowledge creation and intellectual capital. Using social capital as the clustering variable, this study shows that firms with high levels of social capital create more knowledge-creating activities through externalisation $\left(\mathrm{t}=5.444^{* * *}\right)$, combination $\left(\mathrm{t}=4.035^{* * *}\right)$, socialisation $\left(\mathrm{t}=3.537^{* * *}\right)$, and internalisation $\left(\mathrm{t}=3.420^{* * * *}\right)$ of knowledge. Furthermore, firms with higher levels of social capital tend to achieve higher levels of human capital $\left(\mathrm{t}=5.269^{* * *}\right)$, customer capital $\left(\mathrm{t}=4.296^{* * * *}\right)$, and structural capital $\left(\mathrm{t}=5.166^{* * * *}\right)$. Finally, firms with higher levels of social capital tend to achieve higher levels of KM effectiveness $\left(\mathrm{t}=3.958^{* * *}\right)$. These results findings strongly support Hypothesis 6 above. 
Table 6 Comparisons between firms with different levels of social capital

\begin{tabular}{lcccccc}
\hline & \multicolumn{2}{c}{$\begin{array}{c}\text { High social capital } \\
(N=64)\end{array}$} & \multicolumn{2}{c}{$\begin{array}{c}\text { Low social capital } \\
(N=70)\end{array}$} & & \\
\cline { 2 - 5 } Research variable & Mean & S.D. & Mean & S.D. & t-value & P-value \\
\cline { 2 - 5 } Social capital & 5.482 & $(0.485)$ & 3.988 & $(0.564)$ & 16.492 & .000 \\
Externalisation & 4.609 & $(1.072)$ & 3.640 & $(0.981)$ & 5.444 & .000 \\
Combination & 5.302 & $(1.187)$ & 4.452 & $(1.250)$ & 4.035 & .000 \\
Socialisation & 4.474 & $(1.085)$ & 3.729 & $(1.349)$ & 3.537 & .001 \\
Internalisation & 5.410 & $(0.894)$ & 4.825 & $(1.085)$ & 3.420 & .001 \\
Human capital & 5.169 & $(0.962)$ & 4.313 & $(0.913)$ & 5.269 & .000 \\
Customer capital & 5.365 & $(0.844)$ & 4.626 & $(1.137)$ & 4.296 & .000 \\
Structural capital & 4.933 & $(1.026)$ & 4.026 & $(0.995)$ & 5.166 & .000 \\
KM effectiveness & 5.319 & $(0.939)$ & 4.645 & $(1.034)$ & 3.958 & .000 \\
\hline
\end{tabular}

The above results conform to those in the previous literature, Bourdieu [37] and Uzzi [8] contended that social capital should be embedded within networks of mutual acquaintance and recognition. Moreover, Ring \& Van de Ven [10] stated that as social capital continues to be nurtured, informal control mechanisms could replace formal ones. Thus, firms with higher levels of social capital should be encouraged to engage in more knowledge-creating activities. Notably, firms with higher levels of social capital also tend to achieve higher intellectual capital, and ultimately higher KM effectiveness.

\subsection{Comparisons of research factors between firms with different levels of business operation mode (authority delegation)}

Table 7 shows the effects of authority delegation on factors related to knowledge creation and intellectual capital. Using the factor of authority delegation as the clustering variable, firms with high delegation level of authority create more knowledge-creating activities through externalisation $\left(t=2.644^{* * *}\right)$, combination $(t=1.304)$, socialisation $(t=1.567)$, and internalisation of knowledge $(t=1.890)$. Furthermore, firms with higher levels of authority delegation tend to acquire higher levels of human capital $\left(\mathrm{t}=3.428^{* * * *}\right)$, customer capital $\left(\mathrm{t}=3.306^{* * *}\right)$, and structural capital $\left(\mathrm{t}=2.657^{* * *}\right)$. Finally, firms with higher levels of social capital tend to achieve higher levels of $\mathrm{KM}$ effectiveness $\left(\mathrm{t}=2.848^{* * *}\right)$. Thus, the fifth hypothesis above is also supported. 
Table 7 Comparisons between firms with different levels of delegation of authority

\begin{tabular}{lcccccc}
\hline & \multicolumn{2}{c}{$\begin{array}{c}\text { High delegation } \\
(N=73)\end{array}$} & \multicolumn{2}{c}{$\begin{array}{c}\text { Low delegation } \\
(N=61)\end{array}$} & & \\
\cline { 2 - 5 } Research variable & Mean & S.D. & Mean & S.D. & t-value & P-value \\
\cline { 2 - 5 } $\begin{array}{l}\text { Delegation of } \\
\text { authority }\end{array}$ & 8.119 & $(1.351)$ & 3.705 & $(1.403)$ & 18.445 & .000 \\
Externalisation & 4.334 & $(1.101)$ & 3.826 & $(1.113)$ & 2.644 & .009 \\
Combination & 4.991 & $(1.269)$ & 4.699 & $(1.303)$ & 1.304 & .195 \\
Socialisation & 4.242 & $(1.285)$ & 3.896 & $(1.261)$ & 1.567 & .120 \\
Internalisation & 5.260 & $(0.934)$ & 4.918 & $(1.127)$ & 1.890 & .061 \\
Human capital & 4.992 & $(0.932)$ & 4.398 & $(1.050)$ & 3.428 & .001 \\
Customer capital & 5.257 & $(0.841)$ & 4.647 & $(1.219)$ & 3.306 & .009 \\
Structural capital & 4.694 & $(0.992)$ & 4.189 & $(1.174)$ & 2.657 & .001 \\
KM effectiveness & 5.200 & $(0.905)$ & 4.689 & $(1.131)$ & 2.848 & .005 \\
\hline
\end{tabular}

The above findings correspond with the previous literature. Johnston [31] proposed that employees in a decentralised organisation would be better motivated, due to their authority to make decisions autonomously. Furthermore, such employees will be more sensitive to environmental changes and will respond in more innovative and flexible ways to hostile environments. Thus, this study concludes that firms implement higher delegation of authority will conduct more knowledge-creating activities, acquire higher levels of intellectual capital, and thus have higher KM effectiveness.

\section{Conclusions and suggestions}

\subsection{Conclusions}

The key objectives of this study have been to identify the interrelationships among social capital, business operation mode, and intellectual capital, and to confirm the influence of intellectual capital on KM effectiveness. Several conclusions can be drawn based on the analytical results presented above.

The first conclusion of this study is that social capital, delegation of authority, knowledge-creating activities and intellectual capital are significantly related. The analytical results demonstrate that firms operating in an atmosphere of higher organisational authority delegation that emphasises social interactions with mutual trust and respect tend to enhance knowledge-creating activities and thus accumulate higher intellectual capital. The analytical results also show that firms with higher levels of social capital, including emphasis on organisational vision, social interactions, mutual trust, mutual respect and reciprocity of personal friendship, also display increased knowledge creation and intellectual capital.

The above findings may have several explanations. First, as Nahapiet \& Ghoshal [13] contended that the network of relationships possessed by a department improves knowledge-creating capability. Firms that operate under highly interactive and coordinative situations enable their employees to create a climate of innovation and information sharing. Second, firms that operate under higher levels of authority 
delegation may have more opportunities to create knowledge through externalisation, combination, socialisation, and internalisation. Thus, to promote effective knowledge management, firms should stress social capital and delegation of authority on their daily business operations. Third, Becerra-Fernandez \& Sabherwal [32] suggested that internalisation and externalisation of knowledge-creating activities occurs under the focus task domain, whereas combination and socialisation of knowledge-creating activities is appropriate for the broad task domain. Therefore, the interrelationships between social capital, delegation of authority, knowledge-creating activities and intellectual capital are confirmed.

Intellectual capital, including human capital, customer capital, and structural capital, is a key source of firm competitive advantage. The second conclusion of this study demonstrates that firms with higher levels of intellectual capital perform significantly better than other firms in knowledge management. Several reasons may exist for this phenomenon. First, knowledge is a necessity that can be used to achieve competitive advantage [33]. Second, the emphasis on knowledge can encourage firms to adopt new skill initiatives and strive to acquire competitive advantages. Third, as stated by Olve et al. [34], intellectual capital is critical to corporate market value, and once discovered and exploited can provide an organisation with a new source of competitive advantage [35]. Thus, intellectual capital helps a firm acquire competitive advantages and market value, and consequently effective knowledge management. Therefore, it is important that the three elements of intellectual capital, i.e., human capital, customer capital, and structural capital work together and support one another in a real business operating system to ensure effective knowledge management.

The third conclusion that can be drawn is that a contingency fit exists between knowledge-creating activities and social capital, and influences the accumulation of intellectual capital. Several reasons may contribute to this phenomenon. First, this study argues that knowledge-creating activities will be promoted and intellectual capital will increase if firms operating with high delegation of authority, with an emphasis on informal coordination and communication. Second, firms can also promote knowledge-creating activities by incorporating various social mechanisms and networks into their operating systems. This study suggests that knowledge-creating activities and knowledge management effectiveness will both be enhanced if the social system is embedded within networks of mutual acquaintance and recognition. Firms can only facilitate knowledge exchange in a more free space if they can integrate different facets of social capital. Therefore, contingency fits among social capital, delegation of authority and knowledge-creating activities are required to promote intellectual capital and KM effectiveness.

\subsection{Suggestions for future research}

Although this study achieved some fruitful results, which may contribute to the existing literature, several suggestions can be made for the benefit of academicians and business practitioners. First, this study adopted a cross-sectional research design and examined firms at a single time point. Consequently, directional relationships are unclear and should be inferred logically. Longitudinal research is not viable in this study because of constraints of time and data availability.

Second, empirical validation for the integrated framework is not well established, though parts of the framework and the relationships between variables have been shown 
to be significant. The comprehensive structural equation model appears to indicate that plenty of room remains for revision, and that additional modification of the research model and further validation may be required. Nevertheless, the findings of this study represent a significant contribution for management academicians and practitioners wishing to evaluate knowledge creation, intellectual capital management and KM performance.

Third, the response rate in this study was extremely low. This study gathered research data through a mailed questionnaire survey. It takes time and effort for the researchers to get the answers from the respondents. Moreover, the larger firms were especially unwilling to respond to such mailed questionnaires. Future studies should apply different methods to obtain a better response rate. Face-to-face interviews may provide an effective method of increasing response rate.

\section{Acknowledgment}

The authors would like to thank the National Science Council of the Republic of China, Taiwan for financially supporting this research. The authors would also like to thank two anonymous referees for their comments and valuable suggestions.

\section{References}

1 Wiig, K.M. (1997) 'Knowledge management: an introduction and perspective', Journal of Knowledge Management, Vol. 1, No. 1, pp.6-14.

2 TFPL (1999) Skills for Knowledge Management: A Briefing Paper, London: TFPL.

3 Shariq, S.Z. (1997) 'Knowledge management: an emerging discipline', Journal of Knowledge Management, Vol. 1, No. 1, pp.75-82.

4 Laszlo, K.C. and Laszlo, A. (2002) 'Evolving knowledge for development: the role of knowledge management in a changing world', Journal of Knowledge Management, Vol. 6, No. 4, pp.400-412.

5 Sullivan, P.H. (2000) Value-Driven Intellectual Capital: How to Convert Intangible Corporate Assets into Market Value, New York: John Wiley \& Sons.

6 Stewart, T.A. (1997) Intellectual Capital: The New Wealth of Organizations, New York: Doubleday.

7 Burt, R.S. (1997) 'The contingent value of social capital', Administrative Science Quarterly, Vol. 42, pp.339-365.

8 Uzzi, B. (1997) 'Social structure and competition in interfirm networks: the paradox of embeddedness', Administrative Science Quarterly, Vol. 42, pp.35-67.

9 Reagans, R. and Zuckerman, E.W. (2001) 'Networks, diversity, and productivity: the social capital of corporate R\&D teams', Organizational Science, Vol. 12, No. 4, pp.502-517.

10 Ring, P.S. and Van de Ven, A.H. (1994) 'Developmental processes of cooperative interorganizational relationships', Academy of Management Review, Vol. 19, pp.90-118.

11 Nonaka, I. and Takeuchi, H. (1995) The Knowledge-Creating Company, New York: Oxford University Press.

12 Nerdrum, L. and Erikson, T. (2001) 'Intellectual capital: a human capital approach', Journal of Intellectual Capital, Vol. 2, No. 2, pp.127-135.

13 Nahapiet, J. and Ghoshal, S. (1998) 'Social capital, intellectual capital, and the organizational advantage', Academy of Management Review, Vol. 23, pp.242-266.

14 Brooking, A. (1996) Intellectual Capital: Core Assets for the Third Millennium Enterprise, London: International Thomson Business Press.

15 Edvinsson, L. and Malone, M. (1997) Intellectual Capital: Realizing Your Company's True Value by Finding Its Hidden Roots, New York, NY: Harper Business. 
16 Bontis, N., Keow, W.C. and Richardson, S. (2000) 'Intellectual capital and business performance in Malaysian industries', Journal of Intellectual Capital, Vol. 1, No. 1, pp.85-100.

17 Marshall, A. (1890) Principles of Economics, London: Macmillan.

18 St. Onge, H. (1996) 'Tacit knowledge: the key to the strategic alignment of intellectual capital', Strategy and Leadership, March-April, pp.10-14.

19 Jacobs, J. (1965) The Death and Life of Great American Cities, London: Penguin Books.

20 Coleman, J.S. (1990) Foundations of Social Theory, Cambridge, MA: Harvard University Press.

21 Bourdieu, P. and Wacquant, L. (1992) An Invitation to Reflexive Sociology, Chicago, IL: University of Chicago Press.

22 Walker, G., Kogut, B. and Shan, W. (1997) 'Social capital, structural holes and the formation of an industry network', Organization Science, Vol. 8, No. 2, pp.109-125.

23 Burt, R.S. (1992) Structural Holes: The Social Structure of Competition, Cambridge, MA: Harvard University Press.

24 Putnam, R.D. (1993) 'The prosperous community: social capital and public life', American Prospect, Vol. 13, pp.35-42.

25 Yukl, G. and Fu, P.P. (1999) 'Determinants of delegation and consultation by managers', Journal of Organizational Behavior, Vol. 20, pp.219-232.

26 Richardson, H.A., Amason, A.C., Buchholtz, A.K. and Ferard, J.G. (2002) 'CEO willingness to delegate to the top management team: the influence of organizational performance', The International Journal of Organizational Analysis, Vol. 10, No. 2, pp.134-155.

27 Spreitzer, G.M. and Mishra, A.K. (1999) 'Giving up control without losing control: trust and its substitutes' effects on managers' involving employees in decision making', Group \& Organization Management, Vol. 24, pp.155-187.

28 Bass, B.M. (1990) Bass and Stogdill's Handbook of Leadership, New York: Free Press.

29 Schriesheim, C.A., Neider, L.L. and Scandura, T.A. (1998) 'Delegation and leader-member exchange: main effects, moderators, and measurement issues', Academy of Management Journal, Vol. 41, pp.298-318.

30 Axley, S.R. (1992) 'Delegate: why we should, why we don't and how we can', Industrial Management, Vol. 34, pp.16-19.

31 Johnston, M.A. (2000) 'Delegation and organizational structure in small business', Group and Organizational Management, Vol. 25, No. 1, pp.4-21.

32 Becerra-Fernandez, I. and Sabherwal, R. (2001) 'Organizational knowledge management: a contingent perspective', Journal of Management Information Systems, Vol. 18, pp.23-55.

33 Naquiyuddin, T.N.C.P. and Heong, L.H. (1992) 'Malaysian entrepreneurs', Malaysian Institute of Management, Kuala Lumpur.

34 Olve, N.G., Roy, J. and Wetter, M. (1999) A Practical Guide to Using The Balanced Scoreboard - Performance Drivers, Chichester: John Wiley \& Son.

35 Bontis, N. (1996) 'There's a price on your head: managing intellectual capital strategically', Business Quarterly, Vol. 60, No. 4, pp.40-47.

36 Grant, R.M. (1996) 'Prospering in dynamically-competitive environments: organizational capability as knowledge integration', Organization Science, Vol. 7, No. 4, pp.375-387.

37 Bourdieu, P. (1986) 'The forms of capital', in J.G. Richardson (Ed.) Handbook of Theory and Research for the Sociology of Education, New York: Greenwood.

38 Arbuckle, J.L. and Wothke, W. (1999) Amos 4.0 User's Guide, IL: SmallWaters Corporation.

39 Vigoda, E. (2000) 'Internal politics in public administration systems: an empirical examination of its relationship with job congruence, organizational citizenship behavior, and in-role performance', Public Personnel Management, Vol. 29, No. 2, pp.185-210.

40 Joreskog, K. and Sorbom, D. (1994) Structural Equation Modeling with The SIMPLIS Command Language, Chicago: Scientific Software International. 